\title{
Heterodox Autonomy Doctrine: realism and purposes, and its relevance ${ }^{1}$
}

\author{
Doutrina da Autonomia Heterodoxa: realismo e objetivos, \\ e sua relevância
}

RAÚL BERNAL-MEZA*

Rev. Bras. Polít. Int. 56 (2): 45-62 [2013]

Even though making a comparative analysis with other authors' conceptualization of autonomy is not the main goal of this text, there are references to Escudé (Peripheral realism, 1992; 1995), Russell and Tokatlian (Relational Autonomy, 2002), and Vigevani and Cepaluni (Autonomy through diversification, 2007). Escudé uses the concept of autonomy to support his theoretical proposal, whereas Russell and Tokatlián, and Vigebano and Cepaluni follow the traditional conception of autonomy that started with Jaguaribe and continued with Puig.

The methodological proposal to analyze the relevance of Puig's doctrine is to compare it to the different visions of regionalism that are now in force in Latin America.

\section{Autonomy and integration: past and present}

Surely many of you wonder what is the point of thinking about autonomy and integration in this global world.

We must begin by clarifying our point of view around this—allegedly—global world. There is a clear confrontation between the analysis over globalization and its reality, distinguishing between the process (in global capitalism the current era of mundialization) and the ideology that is part of this era. It implies a vision of the world that did not exist in previous stages of historical capitalism. Our world is that of capitalist world order.

Why should one think over these issues? In the first place, because the bonds of domination-dependency have been modified in their ethos-their

\footnotetext{
1 This paper results from research developed at the Fondo Nacional de Desarrollo Científico y Tecnológico (Fondecyt).

* Raúl Bernal-Meza is Full Professor at the Universidad Nacional del Centro de la Província de Buenos Aires and Professor at the Universidad de Buenos Aires, Buenos Aires, Argentina (bernalmeza@hotmail.com).
} 
appearance-under the dynamics imposed by globalization over international structures, including control over international organisms, such as the United Nation's Security Council, the International Monetary Fund (IMF), the World Trade Organization (WTO), etc.; and the nearly absolute scientific-technological supremacy of capitalist central countries, dynamics that tend to deepen and widen the differences between opposed sectors in world power structure. In the second place, because the best road to overcome underdevelopment and to climb the systemic stratification is integration, not the individualistic alternative (except for those countries whose national attributes of power have potential and capacity for great growth, such as, in our region, Brazil).

Juan Carlos Puig (1987, 19-20) wrote: "que es preciso un profundo reexamen de las doctrinas en boga con respecto a la integración, lo demuestra muy claramente el poco éxito que hasta ahora han tenido los organismos que surgieron y pululan a su conjuro. ¿¿No será que hemos errado el camino? ¿Qué las orientaciones teóricas seguidas no eran las más adecuadas?", applying the most fearful and well-balanced social, political and economic policies.

Therefore, to start our analysis, aiming to enshrine the current concerns that Puig thought at the moment of elaborating his doctrine, it is worth to take into account the concepts, which through these years, have been acquiring other meanings.

To autonomize means to widen the leeway margin and usually implies cutting out the opponents (Puig 1987, 33). When talking about autonomy it must be taken into account that "los grupos humanos disfrutan siempre de un ámbito -amplio o limitado- dentro del cual se desarrollan. Operan, claro está, dentro de un contexto -interno y externo, material y sicológico- del que derivan diversas limitaciones para su accionar. El Estado no es una excepción. Por eso es que siempre puede analíticamente establecerse cuál es su margen potencial de decisión autónoma, vale decir, la posibilidad de desarrollar su ser nacional como lo entienden quienes adoptan (formal y sobre todo realmente) las resoluciones gubernativas (en sentido amplio). Si éstas se ajustan a y agotan tal margen potencial, cabe decir que el margen actual de autonomía del estado coincide con el potencial, lo cual constituye la situación óptima desde el punto de vista de la política nacional. No es fácil ciertamente determinar en forma fehaciente el margen autonómico potencial: se necesitan para ello profundos conocimientos de las disciplinas relevantes y especialmente de Relaciones internacionales (...). Gran parte de los problemas experimentados por gobiernos latinoamericanos en sus relaciones con los países desarrollados se deben justamente a una errónea apreciación del contenido de su margen potencial de decisión autónoma” (Puig 1987, 31). Here, Puig shows that the autonomous margin was much more important than what was generally thought by national power groups.

Concerning integration, he thought of it as a social phenomenon in which two or more human groups adopt a permanent regulation about certain issues, that 
until that moment belonged to their exclusive competence or reserved domain. It is about behaviors that aim to accomplish the resignation of the social groups at stake to individual performance, in certain issues, so to start acting coordinately and with a sense of permanence (Puig 1987, 20-1).

The author aimed to understand the world of International Relations and its theoretical thought from our own (Latin American) perspective. This tradition, whose contributions to International Relations' political-economic theory started with Prebisch in the Economic Commission for Latin America (ECLAC) between 1949 and 1950, has an extended history of multiple efforts ${ }^{2}$. This is the line that Puig follows, in which intellectuals from other countries have too insisted ${ }^{3}$.

In his words, the justification of the need to have our own theoreticalmethodological parameters is understood because: "Por lo general, las pre-teorías, teorías y doctrinas en boga, enfocadas desde el ángulo visual de los recursos de poder que la realidad social internacional ofrecería a los países en desarrollo, enfatizan la posición predominante, virtualmente hegemónica, de las Grandes Potencias, en detrimento del papel que una apreciación más objetiva ofrecería a los países pequeños y medianos. ¿Tal vez, nuevamente, porque tales instrumentos teóricos han sido elaborados por especialistas conectados a los ¿centros?” (Puig 1980, 126).

Those dominant theoretical constructions developed in the centers had, according to our author, serious deficiencies. Explicit or implicitly, International Relations' main doctrines and theories agree on a generic appreciation of basic assumptions on which international regime lays to constitute common features, from which we can synthetize three: a) atomist conception of international community; b) conception of power based in material force; and c) absolute predominance of Super Powers or Great powers, in general (Puig 1980).

\section{Juan Carlos Puig: realist thinker and with intentions}

The work and action of this great international jurist shows the complex interactions between realist visions, which were dominant while he studied and interpreted the dynamics of the international system, and the desires and visions with values and intentions, when he imagined the roads our nations had to walk to reach autonomy of decision and economic development to guarantee its peoples well-being.

Another author, Perina, said that "Puig era -y valga la aparente contradicciónun realista con ideales y optimismo. Era un realista porque estudiaba y proponía una estrategia "posible" de integración y autonomía en el sistema internacional. Nadie como él comprendía y enseñaba los límites que imponen los "repartidores"

2 Regarding this, the work of Eduardo Devés Valdés (2003, 2004) is very interesting, and offers a complete vision of the evolution of Latin American thought in different social areas.

3 In particular-it must be pointed out-about international relations, the thought of Aldo Ferrer (cf. BernalMeza 2005) and of Amado Luiz Cervo (2008). 
del sistema internacional y la impermeabilidad de los bloques a los intentos autonómicos. Su propuesta de autonomía heterodoxa es un ejemplo del realismo y la prudencia que recomendaba para lograr mayores espacios en pos del ideal de autonomía para América Latina" (Perina 1989, 342). His realism was a result of confrontation between powerful States and week and dependent States, in a world of conflict of interests.

Clearly, the Autonomy Doctrine was designed for an international order controlled by the East-West paradigm, and the validity of a permanent conflict between Superpowers. But the complications - and, eventually, opportunitiesthat existed to reach wider autonomy conditions rested within the internal sphere of Latin American societies, in those elites ability to choose roads of dependency or autonomy (Bernal-Meza 2005, 216); and these alternatives are still valid.

\section{Theory and praxis of Autonomy}

The concern about an autonomous foreign policy has been debated since, at least, the Roca-Runciman Treaty. It was with the "Third Position," designed by J.D. Perón, that autonomy became an axis of foreign policy.

It is worth noting that there should be an ideological, strategic and programmatic bond with domestic policy, with domestic development strategy, and with economic and social aspects of governmental policy. All this was supported by the Justicialista doctrine, an alternative between capitalism and socialism integrated by elements of nationalism, the Catholic Church's social doctrine, geopolitical traditions of military formation in Argentina, and influences of trade unionism as a mobilizing force, from a corporate point of view. This would be the matrix of the Third Position, the first specific doctrine of Argentina's foreign policy, because, as Perón himself would say, "en 1946, cuando yo me hice cargo del gobierno, la política internacional argentina no tenía ninguna definición" ${ }^{4}$ (Bernal-Meza 1994, 168-9). As Puig explained, there was coherence between a foreign policy that looked for autonomy and a domestic policy of economic development that aimed towards autarchy.

The search and preservation of national autonomy determined the country's position towards the East-West conflict. Neither the Third Position nor "independent" policies of subsequent governments pointed to favor the détente between the two blocks and to create a world order that gave better possibilities to the countries that defined what later would be known as "South."

Argentina was not equidistant between Washington and Moscow, but opposed to the folding to United States. The no-equidistance meant that it would not be neutral if the conflict got worse, while the not-folding meant that it would

4 "When I took responsibility for the government, in 1946, Argentina's international policy had no definition at all." 
not follow automatically Washington interests. It was about setting the differences of interests typical of great power asymmetries and to differentiate the West's strategic and global conveniences. Perón in all his three presidencies, as well as Arturo Frondizi, and Arturo Illia, took these principles as base for their political relations with Washington (Russell 2010, 252).

For J.C. Puig, the more autonomous an actor is, the more chances it has to develop as understood by its elites, who would accept the challenge to increase their margin of free will.

\section{Heterodox Autonomy Doctrine}

What do we understand by "autonomy" in Puig's epistemological ontology? It is about an autonomic road, which goes from recognition, to a dependency situation, to higher stages that can reach the level of heterodox autonomy or secessionist autonomy. The options go from subordination (of which we must escape) to full autonomy, visible in domestic free will.

Autonomy gives the possibility to adopt fair and balanced causes, while subordination lessens this possibility since it allows the dominant to impose its own criteria. It is true that autonomy does not guarantee by itself clever decisions, and not all imposed policies have to be necessarily harmful. It is about analyzing every situation and reaching conclusions around the decision taken and the policies adopted. Autonomy simply means a trace of justice and efficiency, but historical experience shows that normally the policies fixed by the dominant power are not the best or the fairest ones (Puig 1986, 40).

The Autonomy Doctrine is a "Realist" vision of International Relations (Bernal-Meza 1989, 1994, 2005; Simonoff 2012). The concepts and categories it uses are those of realism, where the idea of zero-sum game in world politics is about power dispute. In his own words, "autonomizar significa ampliar el margen de decisión propia, y normalmente implica recortar el que disfruta el oponente. Salvo casos-límite o atípicos, el logro de una mayor autonomía supone en el corto plazo un juego estratégico de suma-cero en el cual alguien gana lo que otro pierde. Avanza el antiguo cliente; retrocede el antiguo dominante" (Puig 1986, 51).

It is an interpretation, from the point of view of periphery, of world power structure and a roadmap for the possible autonomization process-regarding supreme power-for a country whose ruling class would assume the decision of overcoming dependency. As Simonoff points out "la autonomía fue percibida (por Puig) como el desarrollo del Interés Nacional, objetivado por un uso racional. Sus análisis del sistema internacional se concentraron en la asimetría existente en la relación entre América Latina y los Estados Unidos, los efectos negativos de ellas, pero también de los márgenes de maniobra que permitirían la consecución de los Objetivos Nacionales por parte de las elites que conducen al Estado-nación, siendo éste, su variable de análisis" (Simonoff,2012:32). 
Among its greatest accomplishments is the fact that it was a successful effort to theorize from the periphery and look into the world according to its own perspectives; a tradition that started with the ECLAC at the end of the 1940s. In its contribution about the autonomist performance that Latin American countries should adopt, States autonomy is understood as "la máxima capacidad de decisión propia que se puede lograr, teniendo en cuenta los condicionamientos objetivos del mundo real" (Bologna 1989, 293).

It was designed during the bipolar order, when clear elements that showed the loss of United States hegemonic power started to appear, such as the increase of global strategic power and influence of the former URSS; the inefficacy of Washington to military defeat a small periphery country (North Vietnam); the loss of domestic consensus among Foreign Policy; the crisis of North American political system (that would result into Nixon's resignation); the rising of emergent poles of regional power (the former CEE and the middle powers as India, Nigeria, and Iran), as well as the emergence of bigger powers (military powers as China or economic powers as Japan).

Some events happening in world politics were very important to define the autonomic process from its penultimate to its last stage: from heterodox autonomy to secessionist autonomy. The most important one, I believe, was the path China followed when facing his strategic ally, the USSR, which would go through autonomization to rupture.

The path from "dependency" towards "autonomy" could only take place if the countries improved as regards national viability. The autonomization implied three stages: para-colonial dependency, national dependency, and heterodox autonomy. Afterwards, a "fourth stage" related to rupture could be reached: secessionist autonomy.

Each one of these stages was a theorization of a clear historical period, outside Latin America and/or Argentina. Therefore, Para colonial dependency is a stage in which the states formally have a sovereign government and are no longer colonies, but, actually, the groups that hold real power are an appendix of the governmental apparatus and the real structure of power of another state (the "metropolis," the "dominant power"); this is a situation of para-colonialism situation ${ }^{5}$. National dependency takes place when the groups that hold power rationalize dependency, and set goals that could be part of a "national Project" shared globally in its main features. Dependency is accepted, but subdue to the desire to get as much as possible of it, whether it is due to convenience, or strategy to acquire more autonomy ${ }^{6}$.

Heterodox autonomy is a stage in which the domestic groups that hold power, continue to accept the strategic guiding of the dominant power, but they differ around three important issues: a) the domestic development project, that may or

5 According to Puig's description (1984, 74).

6 Puig $(1984,75)$. 
may not be the same as what the super power wants; b) the international links that are not globally strategic; c) the dissociation between superpowers national interest and the strategic interest of the block. The national group of power does not accept the imposition of political and strategic appreciations that are only related to the superpowers' interest, in the name of the "block"7.

The last stage of autonomy - and not necessarily the most convenient one-, the secessionist autonomy, which means the global challenge to the hegemonic superpower where domestic groups that hold power decide to retreat ${ }^{8}$, without considering the global strategic interests of the hegemonic power that leads the block. The viability factor becomes one of the most important parts of his theory. For its development it was necessary: functional domestic elites committed to change and to the implementation of authentic strategies in favor of autonomy, which meant to acknowledge the condition of "dependent" and the politic will to build an alliance ("Strategic Solidarity" against the dominant). Therefore, a Latin American or regional integration that aimed towards domestic development projects was necessary (Bernal-Meza 2005, 215-6).

\section{The central parts of the Autonomy doctrine}

Puig's interpretation has two central elements: a) autonomist practice, i.e. how groups that hold power understand the international reality and accept (or not) to take further on the "maximum possible capacity of free will in the context of the international system"; and b) the relation between viability, autonomy and integration.

Taking the criteria that Argentina, as well as other Latin American countries, had not yet reached its full autonomy, the Doctrine offered as a starting point a theoretical roadmap to base the national and regional road towards autonomy. The road could not be successfully achieved if the countries did not improve in their viability as well, which not only implied resources but also the elite's conviction to start the road towards autonomy (Bologna 1989).

\section{Integration vision in Puig's thought}

Puig considered that autonomy could be reached through integration; understanding this as an instrument and as a solidary destine of common values. For the author, integration is a social phenomenon, that is, a set of behaviors that take place within human groups. The concept "human group" is also comprehensive: it does not only imply the States but also other groups micro, as societies and enterprises, and macro, as the international community. It is about behaviors that

\footnotetext{
7 Puig $(1984,78)$.

8 Puig $(1984,79)$.
} 
aim to achieve that the social groups give up individual performance to start doing so conjunctly and with a sense of permanence (Puig 1986, 41). It is not a purely state-centric understanding of integration, which has prevailed in every integration Project, except for the Bolivarian Alliance for the Peoples of Our America-Alianza Bolivariana para los Pueblos de Nuestra América (ALBA). It is about integration seen as "social phenomenon," even though the states are the leaders of the process.

\section{What was the integration vision for the region?}

Puig imagined the region as an entity that could turn into an international system — something that further on MERCOSUR would accomplish ${ }^{9}$ — whose normativity, differently from what happened in the international system, was given by that integration vision. As Berasategui $(1989,232)$ points out, in the beginnings of the $1970 s^{10}$, Puig firmly believed that the Latin American subsystem not only should, but also could, move forward to a normativity that meant integration, while the international system could only hope for a more modest juridical focus, that of coexistence between States. Integration, in the traditional concept of autonomy, also serves as permanent alliance.

In Puig's thought, three principles base the development of integration: geographic proximity, interdependence, and similarity (Puig 1981). As Vacchino (1989) points out, regarding the Latin American process, he found "desde el principio, un defecto fundamental en la teoría (y la práctica) de la integración latinoamericana: su unilateralismo" ${ }^{11}$. He sees this unilateral feature in several aspects: a) regarding the nature of the phenomenon, that was down to its economic dimension, specifically its commercial dimension; b) regarding the integration method, because it tried to perform integration based in interdependence, that time the hardest of the integration kinds; c) regarding the actors, which were down to "integration among States," leaving behind other integration types in the different semi-public and sub-public levels (Vacchino 1989, 378-9).

Puig always defended a wider integration, not restricted to economic aspects and the generation of interdependences in that field. By that time, in 1986, he had a very judgmental point of view over the fate of integration. To choose an economic integration based on interdependence was an unsteady, slow path. Integration based on a wide market between very unequal nations, on the other hand, was doomed to inanition and languishing (Puig 1986, 44).

The difference on development levels, a fundamental issue that in every integration project has weakened the process, was a key theme for Puig, who thought integration among countries unequal in their potentials could be

9 Cf. Bernal-Meza (2000).

10 In 1973, when Puig was Minister of Foreign Relations of Campora’s government.

11 "From the beginning, a fundamental flaw in Latin American integration theory (and practice): its unilateralism." 
appeased by solidarity. He pointed out the similarity of "status" is not applicable to Latin America. In fact, one of the main problems interdependent integration has faced, and one of the reasons it has not yet given exceptional results, is the omni-comprehensive diversity of Latin American countries. However, it would be possible to take the road of shared values and alliances. All countries are trying to be more autonomous. There could be differences around the shape or intensity of the autonomic impetus and around the strategies applied, but there is no doubt that the goal pursued is that of increasing national freewill (Puig 1986, 45).

\section{Critiques to the integration style chosen}

Puig's integration was associated to the commercial integration phenomenon and, therefore, to the abolition of customs duty and non-tariff restrictions as a starting point of a growing and deepening process in which the policies related to foreign trade would be first included, and then economic policies in general. It was a monistic and restrictive vision of regional integration. Over time, a more pragmatic focus began to develop, which led to the acceptance of notions like informal integration and Project integration, which in diverse opportunities meant to abandon the monistic focus and substitute it by a less rigorous one, which included conjoint actions in some areas in which it was possible to develop integration and cooperation actions among two or more countries of the region (Puig 1981, 230-1; Vacchino 1989, 383). ${ }^{12}$

This vision of integration is the one that more clearly shows the actual process of regional integration and cooperation: a more flexible and pragmatic style with cooperation initiatives differentiated by issues and areas - which seem to be more complementary than the technical mechanisms used in the past-supported by a vision of political cooperation that gives the region a uniform voice and secures autonomy in decisions regarding regional issues. This seems to be the position of the Union of South American Nations-Unión de Naciones Suramericanas $(\text { UNASUR })^{13}$ —, which became clear after president Lugo's destitution in Paraguay.

\section{The role of alliances in integration vision}

Upon analyzing the possibilities the alliances gave as an instrument of solidary integration, Puig pointed out that it is within the international system and its conditioners that the possibilities of solidary integration should be analyzed, i.e. in unions of States determined to reach certain goals, but which are based on shared values such as autonomy. It is true that to "integrate, whether solidary

12 According to the author, this would be the idea of regional integration followed by the Chilean government of Michelle Bachelet. Cf. Flisfisch (2011).

13 Cf. Luchetti (2012). 
or interdependently, is very difficult if the parts meant to be integrated have controversies. That is why a pacific Alliance that supported a truly operative treaty is very convenient" (Puig 1986).

\section{Current viability of the Autonomy Doctrine}

The current projection of the doctrine is a result of the same elements that it indicated. The logic of the method is based in the need to create interpretation analytical diagrams of their own (Latin American and the developing world's), through the selection of relevant variables that would allow to appreciate-in the sense of identifying the relevant and deep tendencies-the hits and misses so to achieve full autonomy (Puig 1984a, 91).

What are the theoretical supports that maintain its validity? Which are the concepts and categories that allow recognizing its validity?

1. Solidary integration as an alternative to interdependent integration (economical-commercial). Puig's proposal was about solidarity, which means to explore and to make the most of other bases to promote human groups integration: the resemblance of shared values. Given that "omnicomprehensive diversity" has affected interdependent integration, it is possible to take the road of shared values and alliances that Latin American countries could celebrate for their conjoint defense, since there are values that most Latin Americans, peoples and elites, share, being one of them the "autonomy" (Vacchino 1989, 379).

2. The role of political elites. Among other elements, the role of elites showed how the relation with the supreme power was to be handled; how the role that North American enterprises and international corporations played in dependent countries was understood and the perception of the relations with neighbor countries and of integration.

3. Heterodox autonomy is the stage in which the domestic groups that hold power continue to accept the strategic guiding of the dominant power, but differ on three important issues: a) the domestic development project, that may or may not be the same as what the superpower wants; b) the international links that are not globally strategic; c) in the dissociation between superpowers' national interest and the strategic interest of the block. Here, the national group of power does not accept the imposition of political and strategic appreciations, which are only related to the superpower's interest, in the name of the "block," political and strategic appreciations that are only related to the supreme power's interest (paragraph taken from a previous section in this paper). It is clearly applied to the situation that the international system has lived at the end of the Cold War. The imposition and acceptance of the Washington Consensus, 
of the "supreme values universally accepted" 14 and the features of world against terrorism (after the September 11 attacks) must be considered as determinant as the ones produced after the East-West conflict.

It is true that secessionist autonomy has no sense in a unipolar world, after the disappearance of the soviet bloc. However, there is no doubt that the evolution of the international system after Cold War is setting a trend of cultural, religious, and ideological breaking points—as Huntington describes as the "crush of civilizations"-, but today we can better understand the questioning that Western civilization and culture are going through.

4. Puig pointed out—regarding Argentinian foreign policy (there is a wellknown idea that underneath the superficial incoherencies there was a coherent structure that would explain them) — that it was necessary to accept some basic events. The first of them talks about "la existencia de un régimen internacional que se basa en criterios, impuestos o aceptados, de aplicación universal..."15 (Puig 1988, 20).

It is about those principles and criteria (values) that the supreme power imposes and begins to be a part of what subordinates have to follow. The updating of this conditioning started after the end of the bipolar order with the agenda of "Supreme values universally accepted," ${ }^{16}$ especially with matters such as security and alliances.

5. The role integration plays as an instrument of autonomization. In Puig's thought, not all integration is autonomizing — an obvious fact at the light of historical evolution of Latin American integration-, integration being instrumental and its sense, dependable on the set goal. It was about a regional or Latin American integration that should achieve autonomizing goals, supported in national developing issues.

It is not about a commercial interpretation, but an autonomizing one; not as a strategy to widen markets, which is a rebellious answer of the supreme power

14 We have defined this as those who are part of the scenes of the Post-Cold War agenda, under the imperial order, that had substituted the relevant issues of the international agenda of the 1970s and 1980s. These values, which held the new configuration of the international system, such as economic liberalism, human rights, environmental protection, social rights, along with strategic-military issues under new shapes related to new security ideas - excluded the issue of "development" from the agenda. Cf. Bernal-Meza (2000 91-92). Also, they constitute the basis of the instrument that supposedly will help improve the international insertion of the developing countries, under the new political and economic order of globalization. (Bernal-Meza 2000, 155). Some authors had defined them as "Supreme values internationally recognized"; cf. Tullo Vigevani et al. (1999), Globalização e Securança Internacional: a posição do Brasil, in G. Dupas and T. Vigevani (org.), O Brasil e as Novas Dimensōes da Securança Internacional, São Paulo, Editora Alfa-Omega.

15 "The existence of an international regime based on universal application criteria, accepted or imposed." 16 Ibid. 
policy, but in only one aspect, since it reduces dependency regarding bilateral interchange, however it does not question the other types of dependency; it is rather integration understood as framework for integral and solidary development of the peoples that have common origins and destinies; it is a systemic instrument to overcome dependency (Bernal-Meza 1989, 240).

What is its applicability to regional integration and cooperation projects?

In the first place, it is evident that the struggle among enthusiasts and skepticals - which, according to Puig, in the past has always resulted in low profile engagements-keeps on going over the ideal of what is possible. However, typical solidary integration actions, such as the "oil ease" or common action regarding external debt, took place in the past using institutional tools that the very countries have created - as Special Commission for Latin American Coordination (CECLA) or Latin American Economic System (SELA)—, besides hemispheric organisms, such as the Organization of American States (OAS). Those issues, discussed today as "energetic" and "funding" agendas, are highlighted on the proposals of UNASUR and ALBA.

The method points to face the Doctrine to the different visions over regionalism, currently in fashion in the region.

According to our interpretation, the current projects are: open regionalism (whose best example is Chile), neo-protectionism (MERCOSUR, CAN), regional aspiration regionalism (ALBA) and Brazilian Regionalism ${ }^{17}$ (IIRSA, CSN, UNASUR).

Open Regionalism, whose origin can be traced to the North American regionalist project and to the ECLAC epistemic community, matches the ideas of neoliberalism that added the pragmatism and updating. It started in the 1990s and tried to reconcile the unilateral policies of commercial liberalization and opening with a liberal idea of "globalization," being a theorization over the opening process that was taking place in different Latin American countries (Bernal-Meza 2005, 2011).

MERCOSUR has contradictory elements. It was born under the influence of "new regionalism" (open regionalism), as a proposal to replace the protectionist model of import substitution industrialization of the Argentinian-Brazil Integration and Cooperation program (1986). In its origin, MERCOSUR had two main goals: one, economical, the creation of a common market; and the second, political, the creation of an international subsystem. The process of construction of the common market was finished with the Ouro Preto Additional Protocol ${ }^{18}$ (1994), which established the plan to strengthen the customs union; meanwhile its birth as an international subsystem occurred the following year, when the Acuerdo Marco Inter-regional de Cooperación was signed in Madrid between the European

17 We had defined it this way because its origin lays on different Brazilian initiatives.

18 Protocolo Adicional de Ouro Preto. 
Union and the MERCOSUR. This fact showed the international acknowledgment of this sub-regional actor. From these perspectives and as a consequence of not being created to develop industries and technology, its main goal was-besides the increase of interblock commerce-to constitute itself as an international actor. However, since it never could develop a common foreign policy, this goal was left subordinated to economic and commercial aspects.

The regionalism of ALBA, that came to life in 2004, is a project where politics are most important in the integrationist process: a multidimensional integration, that has as central goal the fight against poverty and social development, that desires to pursue the "Patria Grande" of the Bolivarian imaginary; created as an alternative response to the North American project Free Trade Area of the Americas (FTAA) and, in a way, as a critique to current regional economic blocks. It promotes complementarity, solidarity, cooperation, and the overcoming of asymmetries among the countries that are part of it (Quintanar 2012). One of its most relevant features is the search for the people's integration rather than of States', what differentiates it from the rest.

The Brazilian Regionalism, through its different initiatives, is aimed at integration so as to strengthen the region as an independent entity, regarding Washington initiatives, but also regarding its own desires of leadership (BernalMeza 2000, 2010, 2010a). The last regionalist proposal, UNASUR, has been an area of dialogue and political agreement that, without confrontation, moves away from North American custody (Luchetti 2012).

\section{Conclusions: facing integration models against the light of Doctrine theory and Praxis}

There are two key elements that we must point out of Puig's thought that would allow to face the Autonomy Doctrine against the different integration models currently in fashion.

Firstly, the aspiration that the region could build the Bolivarian dream of he "Nation of Republics" (Vacchino 1989), which shortens the state-centric visions of the models in fashion. Secondly, the idea of "Solidary integration," opposed to the idea of integration whose unifying force were the economic-commercial relations.

From these points of view, MERCOSUR, by its economical and Hegelian characteristics (state-centric), in absence of a common foreign policy, could not achieve the solidary ideal. Besides, we should add the uncertainty factor, after recent events: a wider MERCOSUR (recent admission of Venezuela and possible admission of Bolivia and Ecuador) vs. The Pacific Alliance (Chile, Peru, Colombia, Mexico).

Being the union with the dominant power not such a valid alternative to reach autonomy and development, open regionalism is a model that does not match the basis of integration. In this model, "integration into the world," that 
is, global integration does not see the region's integration as an instrument that can maximize the national international insertion by association of interests and goals. Even though it does not necessarily imply excluding them, the mechanisms that inspire global insertion do not match those that the Autonomy Doctrine supported for the regions strengthening in terms of power.

Finally, Brazilian Regionalism has had the mark of a realist and state-centric vision of Brazil's foreign policy and its relation to national development and the strengthening of the state. There is an extended literature about this issue ${ }^{19}$. However, it is worth to highlight this country's historical opposition to create supranational structures. Given its natural (tangible and intangible) power resources, from the realistic point of view, it is almost inconceivable to give up autonomy to small and middle States.

The former leaves ALBA as the only project with social proposals, non-Statecentered, compatible with the Autonomy Doctrine. It is only missing internal and foreign policies in favor of autonomy.

\section{Bibliographic references}

ABARCA AMADOR, Ethel (1998) Algunos elementos teóricos para el análisis de políticas exteriores de pequeños países. Estudios Internacionales, Año XXXI, Julio-Diciembre 1998, No 123-124; p. 88-101.

BERASATEGUI, Vicente (1989) Juan ALBUQUERQUE, José Augusto Guilhon, Org. (1996) Sessenta anos de política externa brasileira 1930-1990. Crescimento, Modernizaçâo e Política Externa, São Paulo, USP-Política Internacional, 385 p.

Carlos Puig. Un gran internacionalista latinoamericano. Mundo Nuevo. Revista de Estudios Latinoamericanos, Año XII, N 2/4, abril diciembre, p. 230-235.

BERNAL-MEZA, Raúl (1989) Los caminos de la autonomía desde una lectura de la obra de Juan Carlos Puig. Mundo Nuevo. Revista de Estudios Latinoamericanos, Año XII, Nº 2/4, abril diciembre, p. 236-240.

BERNAL-MEZA, Raúl (1994), América Latina en la Economía Política Mundial. Buenos Aires: Grupo Editor Latinoamericano.

BERNAL-MEZA, Raúl (1996) La Globalización: ¿Un proceso y una ideología?. Realidad Económica, No 139, abril-mayo, p. 83-99.

BERNAL-MEZA, Raúl (2000) Sistema Mundial y Mercosur. Globalización, Regionalismo y Políticas Exteriores Comparadas. Buenos Aires: Grupo Editor Latinoamericano y Universidad Nacional del Centro de la Provincia de Buenos Aires.

BERNAL-MEZA, Raúl (2004), Política Exterior de Argentina, Brasil y Chile. Perspectiva Comparada. José Flávio Sombra Saraiva, Ed. Foreign Policy and Political Regime. Brasilia: Instituto Brasileiro de Relaçôes Internacionais, p. 237-276.

19 Cf., for example, López (2012), Cervo (2008), Bizzozero (2011), Albuquerque (1996, 1996a, 2000, 2000a), Hakim (2002), Moniz Bandeira (1989, 1995), Lima (1992), Vigevani and Cepaluni (2007), Cervo and Bueno (2011), Brainard and Martínez-Díaz (2009), Quintanar and López (2005), Rapoport and Madrid (2011), and the author Bernal-Meza (2000, 2003, 2004, 2009, 2010, 2010a). 
BERNAL-MEZA, Raúl (2004), Política Exterior de Argentina, Brasil y Chile. Perspectiva Comparada. Denis Rolland \& José Flavio Sombra Saraiva, Eds. Political Regime and Foreign Relations. A Historical perspective, Paris: L'Harmattan, p. 183-212.

BERNAL-MEZA, Raúl (2005) América Latina en el mundo. El pensamiento latinoamericano y la teoría de relaciones internacionales. Buenos Aires: Nuevohacer/Grupo Editor Latinoamericano, $395 \mathrm{p}$.

BERNAL-MEZA, Raúl (2009) Latin American Concepts and Theories and Their Impacts to Foreign Policies. José Flávio Sombra Saraiva, Ed. Concepts, Histories and Theories of International Relations for the $21^{\text {st }}$. Century, Brasilia: IBRI, p. 131-177.

BERNAL-MEZA, Raúl (2010) International Thought in the Lula Era, Amado L. Cervo \& Antonio C. Lessa, Ed. Emerging Brazil under Lula: an assessment on International Relations (2003-2010), Brasilia: Revista Brasileira de Política internacional, Special edition, Año 53, p. 193-213.

BERNAL-MEZA, Raúl (2010a), El pensamiento internacionalista en la era Lula. Estudios Internacionales, $\mathrm{N}^{\circ} 167$, p. 143-172.

BIZZOZERO, Lincoln (2011), Contenido y funcionalidad de BRIC y de UNASUR en la política internacional de Brasil, L. Bizzozero e I. Clemente (coords.), La Política Internacional en un mundo en mutación Montevideo: Universidad de la República, pp. 31-45.

BOLOGNA, Alfredo Bruno (1989) Teorías sobre relaciones internacionales desde una perspectiva sur. Instituto de Altos Estudios de América Latina. Caracas: Universidad Simón Bolívar, pp. 271-361.

BRAINARD, L. and MARTÍNEZ-DÍAZ, L. Eds. (2009) Brazil as an Economic Superpower?, Washington D.C.: Brookings Institution Press, 291 p.

CERVO, Amado Luiz, (2008) Inserção Internacional. Fromação dos conceitos brasileiros. São Paulo: Editora Saraiva, 297 p.

CERVO, A. y BUENO, C. (2011) História da política exterior do Brasil. Brasilia,: Editora $\mathrm{UnB}, 595 \mathrm{p}$.

DEVÉS VALDÉS, Eduardo (2003) El pensamiento Latinoamericano en el Siglo XX. Buenos Aires: Biblos y Centro de Investigaciones Diego Barros Arana; Tomo II, 331 p.

DEVÉS VALDÉS, Eduardo (2004) El pensamiento Latinoamericano en el Siglo XX. Entre la modernización y la identidad Buenos Aires: Biblos y Centro de Investigaciones Diego Barros Arana, Tomo III, 242 p.

ESCUDÉ, Carlos (1992) Realismo Periférico. Fundamentos para la nueva política exterior argentina. Buenos Aires, Planeta, 292 p.

ESCUDÉ, Carlos (1995) El Realismo de los Estados débiles. La política del primer Gobierno Menem frente a la teoría de las relaciones internacionales Buenos Aires: Grupo Editor Latinoamericano, $238 \mathrm{p}$.

FLISFISCH, Ángel (2011) La Política exterior chilena y América del Sur. Estudios Internacionales, $\mathrm{N}^{\circ}$ 168, enero-abril 2011, p. 115-141.

HAKIM, Peter (2002) Brasil e México: duas maneiras de ser global. Política Externa, Vol. 10, $\mathrm{N}^{\circ}$ 4, abril-maio 2002, p. 94-107.

JAGUARIBE, Helio (1970) Dependencia y autonomía en América Latina, Helio JAGUARIBE et. al., La dependencia político-económica de América Latina. México D.F.: Siglo XXI Editores, 297 p. 
JAGUARIBE, Helio (1979) Autonomía periférica y Hegemonía céntrica. Estudios Internacionales, $\mathrm{N}^{\circ} 46$, abril-junio.

JAGUARIBE, Helio (1982), Hegemonía céntrica y Autonomía periférica, Eduardo Hill y Luciano Tomassini Comps., América Latina y el Nuevo Orden Económico Internacional, Buenos Aires: Editorial de Belgrano, p. 17-48.

LIMA, María Regina Soares de (1992) Enfoques analíticos de política exterior: el caso brasileño. Roberto Russell Ed. (1992), Enfoques teóricos y metodológicos para el estudio de la política exterior. Buenos Aires: Grupo Editor Latinoamericano; pp. 53-84.

LÓPEZ, Rodolfo (2012), Nuevo instrumento de regionalismo. Resultados de la iniciativa para la Integración de la Infraestructura Regional Sudamericana (IIRSA), R. Bernal-Meza y S. Quintanar Eds. Regionalismo y Orden Mundial: Suramérica, Europa, China, op. cit., p. 217-239.

LUCHETTI, Javier (2012), La Unión de Naciones Sudamericanas como instancia de diálogo político regional. R. Bernal-Meza y S. Quintanar Eds. Regionalismo y Orden Mundial: Suramérica, Europa, China Buenos Aires: Nuevohacer/Grupo Editor Latinoamericano y Universidad Nacional del Centro de la Provincia de Buenos Aires, p. 285-300.

MONIZ BANDEIRA, Luiz Alberto (1989) Brasil-Estados Unidos. A rivalidade emergente (1950-1988). Rio de Janeiro: Civilização brasileira, 328 p.

MONIZ BANDEIRA, Luiz Alberto (1995), Estado Nacional e Política Internacional na América Latina. O continente nas relações Argentina-Brasil (1930-1992). Brasília: Editora da Universidade de Brasília/Editora Ensaio, 304 p.

MUÑOZ, Heraldo (1987), El estudio de las políticas exteriores latinoamericanas: Temas y enfoques dominantes, Manfred Wilhelmy Comp. La fromación de la política exterior. Los países desarrollados y América Latina, Buenos Aires: Grupo Editor Latinoamericano, p. 287-315.

O’DONNELL, Guillermo y LINK, Delfina (1973) Dependencia y autonomía. Buenos Aires: Amorrortu, 284 p.

PERINA, Rubén (1989) Juan Carlos Puig: latinoamericanista por excelencia. Mundo Nuevo. Revista de Estudios Latinoamericanos, N²/4, abril diciembre, p. 342-343.

PUIG, Juan Carlos (1973) El caso de la International Petroleum Co., J.C. Puig, C. Moneta, C. Pérez Llana y A.L. Carella, Eds. De la Dependencia a la liberación. Política exterior de América Latina, Buenos Aires: Ediciones La Bastilla, p. 11-54.

PUIG, Juan Carlos (1980) Doctrinas internacionales y autonomía latinoamericana, Caracas: Instituto de Altos Estudios de América Latina, Universidad Simón Bolívar, 316 p.

PUIG, Juan Carlos (1981), Estrategia, integración latinoamericana y conexión europea. Mundo Nuevo, No 13-14, julio-diciembre, p. 225-246.

PUIG, Juan Carlos (1984), Introducción, en J.C. Puig Comp. América Latina: Políticas Exteriores Comparadas, Buenos Aires: Grupo Editor Latinoamericano, Tomo 1, p. 24-90.

PUIG, Juan Carlos (1984a), La Política exterior argentina: incongruencia epidérmica y coherencia estructural, J.C. Puig Comp. América Latina: Políticas Exteriores Comparadas, op. cit., Tomo 1, p. 91-169.

PUIG, Juan Carlos (1986), Integración y autonomía de América Latina en las postrimerías del siglo XX, Revista Integración Latinoamericana, № 109, enero-febrero, p. 40-62.

PUIG, Juan Carlos (1987) Integración Latinoamericana y Régimen Internacional. Caracas: Universidad Simón Bolívar, 408 p. 
PUIG, Juan Carlos (1988), Política internacional argentina. Rubén Perina y Roberto Russell Eds. Argentina en el mundo (1973-1987). Buenos Aires: Grupo Editor Latinoamericano, p. 19-45.

QUINTANAR, Silvia (2012), La Alternativa Bolivariana para los Pueblos de Nuestra América (ALBA). Un nuevo proceso de regionalismo latinoamericano. R. Bernal-Meza y S. Quintanar Eds. Regionalismo y Orden Mundial: Suramérica, Europa, China, op. cit., p. 301-321.

QUINTANAR, S. y LÓPEZ, R. (2005), La integración de la Infraestructura Regional en América del Sur (IIRSA) y el Eje MERCOSUR-Chile., R. Bernal-Meza y S.K. Saha Eds. Economía Mundial y Desarrollo Regional. Buenos Aires: Nuevohacer/Grupo Editor Latinoamericano, p. 219-241.

RAPOPORT, M. y MADRID, E. (2011) Argentina/Brasil. De rivales a aliados. Buenos Aires: Capital Intelectual, $354 \mathrm{p}$.

RUSSELL, Roberto (2010) La Argentina del segundo centenario: ficciones y realidades de la política exterior. R. Russell Ed. Argentina 1910-2010. Balance del siglo. Buenos Aires: Taurus, p. 227-307.

RUSSELL, R. y TOKATLIAN, J. (2002) De la autonomía antagónica a la autonomía relacional: una mirada teórica desde el Cono Sur. Perfiles Latinoamericanos: 21, diciembre 2002, p. 159-194.

SOARES DE LIMA, Maria Regina (1990) A economia política da política externa brasileira: uma proposta de análise. Contexto Internacional, $N^{\circ}$. 12, jan/dez, p. 7-27.

SOARES DE LIMA, Maria Regina (2005) A política externa brasileira e os desafios da cooperação Sul-Sul. Revista Brasileira de Política Internacional, Vol. 48, Nº 1, p. 24-59.

VACCHINO, Juan Mario (1989) El pensamiento de Juan Carlos Puig y la integración latinoamericana. Mundo Nuevo. Revista de Estudios Latinoamericanos, Año XII, No 2/4, abril diciembre, p. 377-386.

VIGEVANI, T. y CEPALUNI, G. (2007) A Política Externa de Lula da Silva: A Estratégia da Autonomia pela Diversificação. Contexto Internacional, Vol. 29, N 2, julho/dezembro, p. 273-335.

Submitted in January 7, 2013

Accepted in March 18, 2013

\section{Summary}

The Autonomy Doctrine, elaborated by Juan Carlos Puig, is a realist point of view of International Relations. It is an analysis, from the periphery, about the structure of world power, and a roadmap (from a theoretical point of view) for the longing process of autonomization-regarding hegemonic power-for a country whose ruling class would decide to overcome dependency. The elements its author took into account when analyzing its own context are explained in this text and, afterwards, are reflected over its relevance nowadays. For that purpose, it is necessary to answer certain questions, such as which are the concepts and categories that may explain its relevance, its applicability to regional integration and cooperation models and projects, and what would be the analytical method to compare reality versus ideas, among others. The methodological proposal to analyze the relevance of Puig's doctrine is to compare it to different visions of regionalism that are currently in effect in Latin America.

Keywords: Autonomy Doctrine; Latin America; Regionalism. 


\section{Resumo}

A Doutrina da Autonomia, elaborado por Juan Carlos Puig, é um ponto de vista realista de Relações Internacionais. É uma análise, a partir da periferia, sobre a estrutura de poder mundial, e um roteiro (do ponto de vista teórico) para o processo de desejo de autonomização - relativo ao poder hegemônico - para um país cuja classe dominante iria decidir superar a dependência. Os elementos que seu autor levou em conta ao analisar seu próprio contexto são explicados neste texto e, posteriormente, reflete-se sobre a sua relevância nos dias de hoje. Para tal, é necessário responder a algumas questões, como quais são os conceitos e categorias que podem explicar a sua relevância, a sua aplicabilidade para a integração regional e os modelos e projetos de cooperação, e o que seria o método analítico para comparar realidade versus ideias, entre outros. A proposta metodológica para analisar a relevância da doutrina Puig é compará-la com as diferentes visões de regionalismo que estão agora em vigor na América Latina.

Palavras-chave: Doutrina da Autonomia; América Latina; regionalismo. 